\title{
Hallumi Type Cheese Production Technology and its Nutritive Value
}

\author{
Zarina Kapshakbayeva ${ }^{1}$, Aleksandr Mayorov $^{2}$, Zhanar Moldabayeva $^{1}$, Sholpan Baitukenova ${ }^{3}$, Asiya Utegenova ${ }^{1}$, \\ Eleonora Okuskhanova ${ }^{*}$
}

${ }^{1}$ Shakarim State University of Semey, Kazakhstan

${ }^{2}$ Federal Altai Scientific Center of Agrobiotechnology, Barnaul, Russia

${ }^{3}$ Saken Seifullin Kazakh Agrotechnical University, Astana, Kazakhstan

*Corresponding author E-mail: eleonora-okushan@mail.ru

\begin{abstract}
Nowadays in Kazakhstan the assortment of products produced from goat's milk is currently not so great. The main problem with the lack of products based on goat's milk is that goat's milk, as an industrial raw material, has been little studied. This article ex amines the effectiveness of the use of goat milk in the production of cheese type halloumi. According to the studies, it was found that the use of whole milk for cheese production allows increasing the yield of the finished product. Also an enzyme preparation is selected, which ensures the optimal process of goat's milk proteins coagulation. The article also reflects the results of a comparative analysis of an experimentally produced cheese sample with authentic Halloumi cheese made in Cyprus.
\end{abstract}

Keywords: goat milk, cheese, Halloumi, amino acid, chemical composition.

\section{Introduction}

Today the assortment of cheeses is represented by a large variety. The basic factor in the selection and formation of the preferred assortment of cheeses by the population is a culture of cheese consumption, national characteristics, as well as the level of the country's well-being.

The culture of cheese consumption is one of the effective mechanisms capable of increasing the productive power, the quality level and the range of cheeses, by borrowing the technology of the producing countries, which have its own spectrum of one or another type of cheese.

The development of new technologies for the production of cheeses with a short production cycle is a promising direction in cheesemaking.

It is well known that one of the limiting elements of the production of natural cheeses is the lack of fresh milk which is dependent on lactation period of animals and seasonal nature. However, the development of modern refrigeration technologies, allow preserving and storing the prepared batch of cheeses for a long time, with no compromise in quality, especially organoleptic characteristics of the cheese.

Practical interest from the point of view of the technological process is the Halloumi cheese, the traditional cheese of the island of Cyprus, which is also quite popular in the Middle East and throughout Greece. Cheese "Halloumi" began to be made in $\mathrm{Cy}$ prus in the era of Medieval Byzantium. In 1999, the Cypriots formally established the trade name "Halloumi" behind the island. In addition, industrial and private production of this cheese is flourishing in Cyprus [1].

Now this cheese is produced all over the world. Halloumi has a high melting point, so it can be fried. Halloumi is unusual [2] in that the production of this cheese does not use either acid or acidforming bacteria. Traditionally, this cheese is made from goat or sheep milk, and also from their mixture[3]. This cheese has a white flesh, which has a distinctive layered texture, somewhat resembling Mozzarella. Halloumi has a salty taste. Cheese can last for up to a year if it is kept frozen (below $-18^{\circ} \mathrm{C}$ ) and defrosted to $+4{ }^{\circ} \mathrm{C}$ before putting it on the supermarket shelf. Technological aspects of cheese production from cow's milk, gomogenized and reconstituted milk had been described by Reyad Rashid Shaker [4] in 1988 and its characteristics manufactured from cows', goats' and sheep's milkby PhotisParademas and Richard K Robinson [5]. Unfortunately, in domestic literary sources there is no developed technological scheme for the production of Halloumi cheese. Thus, we faced the task of optimizing the technological processes for the production of Halloumi cheese from goat's milk. This selection of raw materials is due to its unique composition [6], which is natural for our body, does not cause an allergic reaction, is easily and completely absorbed, and similarly to breast milk strengthens the immune system [7].

A feature of the production of cheese from goat's milk is associated with a lesser ability to coagulate with enzymes, which is to some extent explained by the fractional composition of proteins. Calcium chloride has a positive effect on coagulation process by increasing the titrated acidity by $3-5^{0} \mathrm{~T}$. This acidification ensures the rapid coagulation of goat's milk and the formation of a denser clot [8].

The purpose of this study is to determine the chemical, amino acid and fatty acid composition of Hallumi type cheese. 


\section{Materials and methods}

The experimental production of cheese type "Halloumi" was carried out according to the technological scheme, presented in Figure 1.

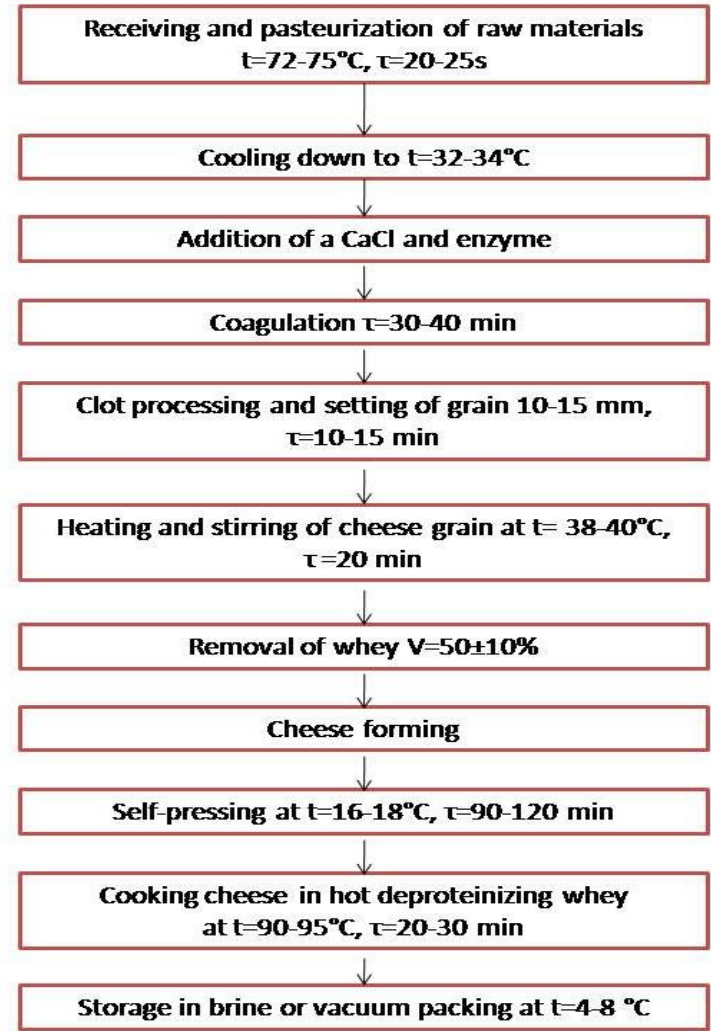

Fig.1: Technological scheme for the production of cheese type "Halloumi"

For a more detailed examination of the process of production of cheese from goat's milk, a detailed description is presented for each stage of the process

1. Receiving and preparing raw materials. In the microbiological sense, the raw material must be benign. Milk for cheese must quickly coagulate under the action of the rennet enzyme, form a clot that separates the whey well.

2. Pasteurization and cooling. Pasteurization of milk is carried out at pasteurization-cooling plants at $\mathrm{t}=72-74{ }^{\circ} \mathrm{C}$ with an exposure time of 20-25 seconds. The purpose of heat treatment is to destroy the vegetative forms of microorganisms, inactivate the enzymes in the native state, prepare the milk for coagulation. In the recovery section, the milk is cooled to the coagulation temperature (32-34 $\left.{ }^{\circ} \mathrm{C}\right)$.

3. Addition of $\mathrm{CaCl}$ and rennet. In the production of cheese, calcium chloride compensates for the low level of calcium in milk after the pasteurization process, since part of the calcium salts during the heat treatment of milk changes from soluble to insoluble state 4. Coagulation and clot processing. Rennet enzyme ensures the formation of a firm clot in a short time. The milk is rolled at $t=32$ $34^{\circ} \mathrm{C}$ for $30-45$ minutes. The resulting clot is cut by lyres, crushed and kneaded for 10-15 minutes with the aim of setting the cheese grain (size 15-20 mm). After the end of the stirring, give the grain to settle for 10 minutes. To accelerate dehydration, the second heating of the cheese grain is carried out under the following conditions: $\mathrm{t}=38-41^{\circ} \mathrm{C}$, duration 15 minutes. The grain size at the end of the treatment is $5-10 \mathrm{~mm}$

5. Removal of whey. The volume of the removed whey is 50-60\% 6. Forming. Cheese is laid out in special shapes and subjected to self-pressing at $\mathrm{t}=18-20^{\circ} \mathrm{C}$, with 3-5 one-time overturning for 1.5-2 hours. The purpose of self-pressing is to compact the cheese mass and remove free whey.
7. Cook cheese in deproteinized serum for 20-30 minutes at a temperature of $85-90{ }^{\circ} \mathrm{C}$ until the temperature inside the cheese reaches $75^{\circ} \mathrm{C}$.

8. Cooling cheese to a temperature of $40-42^{\circ} \mathrm{C}$ and forming. Salting with dry salt in an amount of $5 \%$.

9. Storage. Store the product at a temperature of $4-8{ }^{\circ} \mathrm{C}$ for 2 months, at a temperature of $-18^{\circ} \mathrm{C}$ for 12 months.

The study followed standardized methods for investigating properties of goat's milk according to GOST 32259-2013; GOST 362492; GOST 5867-90

Coagulation activity of enzyme preparations was determined according to National Standard GOST ISO 11815-2015

The quality of the finished product is determined by GOST 362673; GOST 9225-84; GOST 32260-2013; GOST 3622-68; GOST 26932-86

Environmental safety analysis was undertaken to determine the contents of toxic elements as follows:

-mass fraction of mercury GOST 26927-86

-mass fraction of plumbum GOST 26932-86

-mass fraction of arsenic GOST 26930-86

-mass fraction of cadmium GOST 26933-86

-mass fraction of aflatoxins B (1) and M (1) GOST 30711-2001

- mass fraction of cesium and strontium GOST 32164-2013

- mass fraction of pesticides MU 2142-80

For the purpose of milk normalization, the method of square mixing was used. In the upper left corner indicate the fat content of the milk to be normalized, in the lower left corner - the fat content of skim milk or milk with a fat content below $3.2 \%$, which also can normalize whole milk, in the center - the fat content of normalized milk. Then, on the diagonal from larger numbers subtract smaller and the resulting differences are placed at the corners of the right side of the square. The differences show the ratio between whole and skim milk on which it is necessary to form a mixture in order to obtain normalized milk [9].

In order to determine the milk-clotting activity $5 \mathrm{ml}$ of the substrate were poured into thin-walled glass vials, heated in a water bath at $35^{\circ} \mathrm{C}$ and held for three minutes, then $0.1 \mathrm{ml}$ of the enzyme preparation prepared according to GOST ISO 11815-2015 was added immediately stopwatch, and the contents of the tube immediately mixed. The beginning of the coagulation reaction was determined by the formation of flakes in a drop of milk applied to the walls of the tube with a glass rod. After determining the beginning of the clotting, the stopwatch was immediately switched off. For preparing the enzyme preparation, $1 \mathrm{~g}$ of the sample of the enzyme preparation was dissolved in $80.0 \mathrm{~cm} 3$ of distilled water at a temperature of $35^{\circ} \mathrm{C}$, stirred for 30 minutes, the total volume was adjusted to $100.0 \mathrm{~cm} 3$ and insisted in a water bath at $35^{\circ} \mathrm{C}$ for 15 minutes [14].

Amino-acid analysis has been performed in hydrolyzates of solid product applying automated amino-acid analyzer Type AAA-339. Fatty acid composition of the fat phase of goat milk was carried out by gas chromatography, carried out in accordance with GOST 32915-2014.

The results of the study have been statistically processed. Absolute and relative values (extensive parameters) have been applied. Confidence estimation of the statistic indicators was carried out applying arithmetic and geometric mean values (M), mean error (m), Student's coefficient $(\mathrm{t})$, probability level of confidence interval P.Interconnections between the phenomena were determined applying coefficient of concordance, criterion $\chi^{2}$.

\section{Results and discussions}

In view of the foregoing, we faced the challenge of determining the effectiveness of using whole and normalized goat milk for making halloumi cheese. In order to normalize the milk for an optimal ratio of fat and protein 1: 1,1 [11] the mixing square 
method was used. The physico-chemical properties of milk are presented in Table 1.

Table 1: Physico-chemical properties of raw milk

\begin{tabular}{|l|l|l|l|l|l|l|}
\hline $\begin{array}{l}\text { Type of } \\
\text { milk }\end{array}$ & $\begin{array}{l}\text { Fat, } \\
\%\end{array}$ & $\begin{array}{l}\text { Pro- } \\
\text { tein, } \%\end{array}$ & $\begin{array}{l}\text { Nonfat } \\
\text { milk } \\
\text { solids } \\
\text { (NMS), } \\
\%\end{array}$ & $\begin{array}{l}\text { Milk } \\
\text { densi- } \\
\text { ty, } \\
\mathrm{kg} / \mathrm{m} 3\end{array}$ & $\begin{array}{l}\text { Pro- } \\
\text { tein: } \\
\text { Fat } \\
\text { ratio }\end{array}$ & $\begin{array}{l}\text { Pro- } \\
\text { tein: } \\
\text { NMS } \\
\text { ratio }\end{array}$ \\
\hline $\begin{array}{l}\text { Whole } \\
\text { milk }\end{array}$ & $\begin{array}{l}4,8 \\
3\end{array}$ & 3,43 & 9,05 & 1034 & $1: 1,4$ & 0,38 \\
\hline Skim milk & $\begin{array}{l}1,2 \\
5\end{array}$ & 3,63 & 9,67 & 1035 & $1: 2,3$ & 0,37 \\
\hline $\begin{array}{l}\text { Normal- } \\
\text { ized milk }\end{array}$ & $\begin{array}{l}3,4 \\
0\end{array}$ & 3,63 & 9,43 & 1033 & $1: 1$ & 0,38 \\
\hline
\end{tabular}

According to the results of the development, it was found that the protein coagulation process, namely the clot density and clotting time, was identical in both samples. The results of studying the technological and physico-chemical properties of goat milk and cheese, produced from whole and normalized milk, are presented in Table 2.

Table 2: Technological and physicochemical properties of raw milk and cheese produced from whole and normalized goat milk

\begin{tabular}{|l|l|l|}
\hline Component & $\begin{array}{l}\text { Whole } \\
\text { goats' milk }\end{array}$ & $\begin{array}{l}\text { Normalized } \\
\text { goats' milk }\end{array}$ \\
\hline Coagulation time, min & $30 \pm 2$ & $30 \pm 2$ \\
\hline Milk pH & 6,6 & 6,6 \\
\hline Whey pH & 6,2 & 6,2 \\
\hline Cheese pH & 6,2 & 6,2 \\
\hline $\begin{array}{l}\text { The yield of cheese after self- } \\
\text { pressing \% }\end{array}$ & 22,6 & 20,8 \\
\hline The yield of cheese after cooking, \% & 16,4 & 15 \\
\hline $\begin{array}{l}\text { Loss of cheese mass in the process of } \\
\text { cooking, \% }\end{array}$ & 6,2 & 5,8 \\
\hline The yield of whey proteins, \% & 10 & 6,8 \\
\hline Mass fraction of protein in cheese, \% & 43,6 & 41,4 \\
\hline Mass fraction of fat in cheese, \% & 47,1 & 42,8 \\
\hline Moisture content of cheese, \% & 44,4 & 46.6 \\
\hline $\begin{array}{l}\text { Mass fraction of moisture in non- } \\
\text { fatty matter(MSNF), \% }\end{array}$ & 49.9 & 52,2 \\
\hline
\end{tabular}

As can be seen from the table, the yield of cheese from whole milk is higher by $1.8 \%$ than cheese produced from normalized milk. According to the chemical composition, cheese, produced from whole goat milk, is characterized by higher protein and fat content.

When preparing whey used for cheese heat treatment (cooking), an albuminous mass suitable for the production of soft cheeses, such as ricotta, is produced. When the whey serum was heated, the yield of whey proteins was higher by $3.2 \%$ in serum derived from whole milk. However, the loss of cheese after cooking in hot whey is less for cheese produced from normalized milk by $0.4 \%$ than for cheese made from whole milk

The next stage of the study was the choice of the enzyme preparation and the determination of an adequate dose of enzyme addition, which ensures the optimal coagulation process.

Milk clotting enzyme preparations can be divided into two groups: the first - a rennet enzyme; the second is enzymes of plant, microbial origin, recombinant chymosin [12].

Milk clotting enzymes are a key component in the production of natural cheeses. Optimal milk clotting activity - one of the main characteristics that affect the quality of the clot in the production of cheese [13].

As a substrate for the determination of coagulation activity, whole goat milk was $4.83 \%$ fat and with a protein content of $3.71 \%$. In accordance with the standard research method, goat milk was pasteurized at a temperature of $71 \pm 2{ }^{\circ} \mathrm{C}$ with an exposure time of $20-25 \mathrm{~s}, 30 \mathrm{~g}$ of calcium chloride were added per $100 \mathrm{~kg}$ of milk. The introduction of calcium chloride ensures the rapid coagulation of goat milk and the formation of a denser clot. The varia- ble coagulation factors, the type and amount of the enzyme preparation have been taken as factors of research. Three types of enzyme preparations of animal and plant origin were studied.

The results of the clotting time of goat milk and cow milk, which was used as a control, of all enzyme preparations are presented in Table 3.

Table 3: Coagulation time of goat milk by various enzyme preparations

\begin{tabular}{|c|c|c|c|c|c|}
\hline \multicolumn{6}{|c|}{ Clotting time, seconds } \\
\hline \multicolumn{2}{|c|}{$\begin{array}{l}\text { Rennet pepsin SP- } \\
70 \text { “Tradition" }\end{array}$} & \multicolumn{2}{|c|}{$\begin{array}{l}\text { Rennet pepsin SG-50 } \\
\text { «Normal» }\end{array}$} & \multicolumn{2}{|c|}{ Reniplus } \\
\hline M1* & $\mathrm{M} 2 * *$ & M1 & M2 & M1 & M2 \\
\hline 177 & 159 & 160 & 143 & 127 & 104 \\
\hline 175 & 157 & 158 & 141 & 127 & 107 \\
\hline 177 & 155 & 156 & 145 & 124 & 102 \\
\hline 178 & 155 & 156 & 140 & 121 & 104 \\
\hline 174 & 154 & 155 & 141 & 123 & 102 \\
\hline \multicolumn{6}{|c|}{ The arithmetic mean of the clotting time, seconds } \\
\hline 176 & 156 & 157 & 142 & 124 & 104 \\
\hline
\end{tabular}

Based on the results of measuring the coagulation time, it can be concluded that the microbial enzyme Reniplus

The next stage of the study was to determine the activity of enzyme preparations doses for coagulation of goat's milk. The results of the study are presented in Table 4.

Table 4: Determination of the activity of doses of enzyme preparations Enzyme dose, g/100 kg $\quad$ Milk clotting time, min

\begin{tabular}{|l|l|l|l|}
\cline { 2 - 4 } & $\mathrm{t} 1=34-350 \mathrm{C}$ & $\mathrm{t} 2=32-330 \mathrm{C}$ & $\mathrm{t}=30-310 \mathrm{C}$ \\
\hline Rennet pepsin SP-70 “Tradition" \\
\hline 0,5 & $75 \pm 2$ & $75 \pm 1$ & $76 \pm 2$ \\
\hline 1,0 & $44 \pm 1$ & $44 \pm 1$ & $47 \pm 1$ \\
\hline 1,5 & $41 \pm 2$ & $40 \pm 2$ & $43 \pm 1$ \\
\hline \multicolumn{3}{|l|}{} \\
\hline 0,5 & $74 \pm 2$ & $74 \pm 2$ & $75 \pm 1$ \\
\hline 1,0 & $42 \pm 1$ & $43 \pm 1$ & $46 \pm 1$ \\
\hline 1,5 & $40 \pm 2$ & $40 \pm 2$ & $44 \pm 2$ \\
\hline Microbial enzyme Reniplus for goat's milk \\
\hline 0,5 & $57 \pm 1$ & $55 \pm 2$ & $56 \pm 2$ \\
\hline 1,0 & $25 \pm 1$ & $25 \pm 1$ & $26 \pm 1$ \\
\hline 1,5 & $21 \pm 2$ & $19 \pm 1$ & $20 \pm 1$
\end{tabular}

The analysis of data makes it possible to consider the most optimal dose of application of the enzyme preparation $1.5 \mathrm{~g} / 100 \mathrm{~kg}$ for all the enzyme preparations studied, which allows obtaining a good quality clot for the optimal coagulation time of goat milk Despite the impressive results of the milk-clotting activity of the microbial enzyme Reniplus, it was decided not to use it in the production of cheese. One of the decisive factors was insufficient information and research on microbial enzymes, which in turn does not guarantee the quality and provision of food safe finished product. According to studies conducted by M.V. Polkovnikova and L.N. Azolkina, showed that in clots obtained with the use of preparations of animal origin, the whey is separated more evenly than from the clot obtained with the use of the recombined drug. Microbial and recombined enzyme preparations form a softer clot in comparison with enzyme preparations of animal origin [15].

According to our experimental studies, preference was given to the enzyme preparation of animal origin SG-50, since the use of this enzyme had a more successful experience of effective use in the production of cheese of the Halloumi type.

As a result of the study of the milk-clotting activity of enzyme preparations in the production of cheese type Halloumi from goat's milk, an optimal dose of enzyme preparations has been established.

The final stage of our research was the comparative evaluation of the cheese produced from goat's milk with Cypriot cheese "Hal- 
loumi" from sheep's milk. Information on the physicochemical composition of the Halloumi cheese produced in Cyprus is represented by scientists Anifantakis E.M. and Kominaridis S.E. (1983) [16]. The results of the study are presented in Table 5.

Table 5: Comparative characteristics of Halloumi cheese

\begin{tabular}{|c|c|c|c|c|c|c|}
\hline \multirow[t]{2}{*}{$\begin{array}{l}\text { Physicochem- } \\
\text { ical character- } \\
\text { istic }\end{array}$} & \multicolumn{3}{|c|}{$\begin{array}{l}\text { Cheese "Halloumi" devel- } \\
\text { oped in experimental } \\
\text { conditions }\end{array}$} & \multicolumn{3}{|c|}{$\begin{array}{l}\text { Cheese "Halloumi" made } \\
\text { in Cyprus }\end{array}$} \\
\hline & $\begin{array}{l}\text { Mea } \\
n\end{array}$ & $\begin{array}{l}\text { Val- } \\
\text { ues } \\
\text { range }\end{array}$ & $\begin{array}{l}\text { Stand- } \\
\text { ard } \\
\text { devita- } \\
\text { tion }\end{array}$ & $\begin{array}{l}\text { Mea } \\
n\end{array}$ & $\begin{array}{l}\text { Val- } \\
\text { ues } \\
\text { range }\end{array}$ & $\begin{array}{l}\text { Standart } \\
\text { devita- } \\
\text { tion }\end{array}$ \\
\hline Moisture \% & $\begin{array}{l}47,1 \\
5\end{array}$ & $\begin{array}{l}46,5- \\
47,6\end{array}$ & 0,91 & $\begin{array}{l}43,5 \\
3\end{array}$ & $\begin{array}{l}35,46 \\
- \\
48,56 \\
\end{array}$ & 3,75 \\
\hline $\begin{array}{l}\text { Moisture in } \\
\text { non fat sub- } \\
\text { stance, } \%\end{array}$ & 52,2 & - & - & $\begin{array}{l}57,1 \\
4\end{array}$ & - & - \\
\hline $\begin{array}{l}\text { Salt in mois- } \\
\text { ture, } \%\end{array}$ & 2,5 & - & - & 8,32 & - & - \\
\hline $\begin{array}{l}\text { Fat in dry } \\
\text { matter, \% }\end{array}$ & 44,8 & $\begin{array}{l}42,6- \\
47,1\end{array}$ & 3,15 & $\begin{array}{l}44,5 \\
2\end{array}$ & $\begin{array}{l}37,95 \\
- \\
50,48\end{array}$ & 3,98 \\
\hline Protein, \% & 42,5 & $\begin{array}{l}41,4- \\
43,6\end{array}$ & 1,5 & $\begin{array}{l}24,4 \\
6\end{array}$ & $\begin{array}{l}20,86 \\
- \\
30,45\end{array}$ & 2,28 \\
\hline
\end{tabular}

As can be seen, from the table, the cheese produced under experimental conditions from goat's milk according to the protein content has great advantages. According to the content of table salt, the authentic Halloumi cheese has a higher concentration. However, according to Kazakh domestic standards, the salt concentration for semisolid cheeses should be in the range of 0.2-4.0 [17].

An amino acid and fatty acid composition was performed to evaluate the biological value of the cheese produced in the experimental conditions.

The results of the amino acid composition are presented in the table 7

As can be seen, from the table, the cheese produced under experimental conditions from goat's milk according to the protein content has great advantages. According to the content of table salt, the authentic Halloumi cheese has a higher concentration. However, according to Kazakh domestic standards, the salt concentration for semisolid cheeses should be in the range of 0.2-4.0 [17].

An amino acid and fatty acid composition was performed to evaluate the biological value of the cheese produced in the experimental conditions.

The results of the amino acid composition are presented in the table 6

Table 6: Amino acid composition of Halloumi cheese

\begin{tabular}{|c|c|}
\hline Amino acid & Mean, mg in $100 \mathrm{~g}$ of protein \\
\hline Aspartic acid & 2438,63 \\
\hline Glutamic acid & 5816,23 \\
\hline Serine & 1507,91 \\
\hline Histidine & 1028,64 \\
\hline Glycine & 450,42 \\
\hline Threonine & 1397,63 \\
\hline Arginine & 1067,80 \\
\hline Alanine & 1185,30 \\
\hline Tyrosine & 1028,64 \\
\hline Cysteine & 293,64 \\
\hline Valine & 1870,72 \\
\hline Methionine & 783,33 \\
\hline Phenylalalanine & 1331,66 \\
\hline Leucine & 2917,91 \\
\hline Isoleucine & 1684,16 \\
\hline Lysine & 2281,97 \\
\hline Tryptophan & 411,25 \\
\hline Proline & 2654,05 \\
\hline
\end{tabular}

The analysis of the obtained results indicates a wide spectrum of free amino acids in the goat cheese produced. Cheese protein is well balanced and contains all the essential amino acids.

The results of the fatty acid composition of halloumi cheese from goat's milk are presented in the table 7 .

Table 7: Fatty acid composition of Halloumi cheese

\begin{tabular}{|l|l|}
\hline Fatty acid composition, \% & Mean \\
\hline Saturated fatty acid & 67,968 \\
\hline Oilyacid & 2,397 \\
\hline Nylonacid & 2,946 \\
\hline Caprylicacid & 3,506 \\
\hline Capricacid & 10,747 \\
\hline Lauricacid & 5,042 \\
\hline Myristicacid & 9,250 \\
\hline Pentadecanoicacid & 0,767 \\
\hline Palmiticacid & 23,531 \\
\hline Margarineacid & 0,540 \\
\hline Stearic acid & 8,932 \\
\hline Behenicacid & 0,146 \\
\hline Lignocericacid & 0,182 \\
\hline Monounsaturated fatty acid & 27,647 \\
\hline Pentadeceneacid & 0,295 \\
\hline Palmitoleicacid & 0,347 \\
\hline Margarineacid & 0,301 \\
\hline Octadeceneacid & 0,068 \\
\hline Oleicacid & 26,636 \\
\hline Polyunsaturated fatty acid & 4,367 \\
\hline Linoleidin acid & 0,531 \\
\hline Llinoleic acid & 2,447 \\
\hline Linolenic acid & 0,990 \\
\hline Y-linolenic acid & 0,399 \\
\hline Total & 100 \\
\hline Analysis the & \\
\hline
\end{tabular}

Analysis of the results of the studies shown that the produced cheese is characterized by a full fatty acid composition.

The next step of our research was a comparative analysis of the physico-chemical properties of fresh cheese and cheese, stored at $18^{\circ} \mathrm{C}$ for 3 months. The results of the studies are presented in Table 8 .

Table 8: Comparative characteristics of fresh and defrosted cheese

\begin{tabular}{|l|l|l|}
\hline Indicators & $\begin{array}{l}\text { Fresh } \\
\text { cheese }\end{array}$ & $\begin{array}{l}\text { Defrosted } \\
\text { cheese }\end{array}$ \\
\hline Moisture content, \% & 46,6 & 49,8 \\
\hline $\begin{array}{l}\text { Mass fraction of moisture in non-fatty } \\
\text { matter, \% }\end{array}$ & 52,2 & 56,3 \\
\hline Mass fraction of salt, \% & 2,0 & 2,0 \\
\hline Mass fraction of fat in dry matter, \% & 42,8 & 40,2 \\
\hline Mass fraction of protein, \% & 43,6 & 40,7 \\
\hline QMAFAnM, CFU/g & $1 * 103$ & $1 * 103$ \\
\hline Coliform bacteria in $1.0 \mathrm{~g}$ & Not detected \\
\hline $\begin{array}{l}\text { Pathogenic microorganisms, including } \\
\text { Salmonella }\end{array}$ & Not detected \\
\hline $\begin{array}{l}\text { S. aureus } \\
\text { Listeria monocytogenes }\end{array}$ & Not detected \\
\hline The content of yeasts and molds & \multicolumn{2}{|l|}{ Not detected }
\end{tabular}

The results of physico-chemical and microbiological investigation show that defrosted cheese has not lost its physico-chemical properties. It should be noted that in microbiological aspects fresh and defrosted cheeses are safe.

We conducted research to determine the indicators of safety of cheese based on goat milk. The results of the study are presented in Table 9.

Table 9: Food safety of the finished product

\begin{tabular}{|l|l|l|}
\hline Indicators, units of measurements & $\begin{array}{l}\text { Permissible } \\
\text { level }\end{array}$ & $\begin{array}{l}\text { Actually re- } \\
\text { ceived }\end{array}$ \\
\hline Toxic elements mg/kg, not more: & & Not detected \\
Lead & 0,5 & Not detected \\
Arsenic & 0,3 & Not detected \\
Cadmium & 0,2 & Not detected \\
Mercury & 0,03 &
\end{tabular}




\begin{tabular}{|l|l|l|}
\hline $\begin{array}{l}\text { Mycotoxins, mg/kg not more: } \\
\text { Aflatoxin M1 }\end{array}$ & 0,0005 & Not detected \\
\hline $\begin{array}{l}\text { Pesticides mg / kg, not more than } \\
\begin{array}{l}\text { Hexachlorocyclohexane }(\alpha, \beta, \gamma- \\
\text { isomers) }\end{array}\end{array}$ & 1,25 & Not detected \\
$\begin{array}{l}\text { DDT and its metabolites } \\
\text { Antibiotics, mg / kg, not more than: }\end{array}$ & 1,0 & Not detected \\
$\begin{array}{l}\text { Levomycytin } \\
\text { Tetricycline group }\end{array}$ & Not allowed & Not detected \\
\hline $\begin{array}{l}\text { Radionuclides Bq / kg, not more } \\
\text { than: }\end{array}$ & 50 & Not detected \\
$\begin{array}{l}\text { Cesium-137 } \\
\text { Strontium-90 }\end{array}$ & 100 & 7,7 \\
\hline
\end{tabular}

The presence of toxic elements, mycotoxins, pesticides, as well as antibiotics in the investigated object were not detected, the presence of heavy metal salts were found within the permissible norm.

\section{Conclusion}

Thus, in the course of experimental studies, optimal conditions for the use of goat milk for the production of Halloumi cheese were identified. In the course of the study, it was found that it is more effective to produce cheese from whole milk, which guarantees a high yield of cheese and will reduce the cost of normalizing raw materials. In addition, the milk-clotting activity of enzyme preparations in goat milk environment was studied. The optimum enzyme preparation SG-50 "Normal" was chosen by experiment and the dose of its application is $1.5 \%$

Also, the biological value of cheese is determined, namely, amino acid and fatty acid composition. Comparative characteristic of the experimentally produced cheese with authentic Cypriot cheese is made, the results of which show a worthy match with the original sample. In conclusion, it is worth noting that the obtained results provide the foundation for the further development of technology of cheese "Halloumi" from goat's milk. The organization of this kind of production will allow to expand the assortment of the cheese market and reduce import of imported cheeses having much higher prices.

\section{References}

[1] Robinson RK, Haddadin MSY, Abdullah BM (1991), Halloumi cheese-some aspects of manufacture and quality. South African Journal of Dairy Science, 23, 61-64.

[2] Anifantakis EM, Kaminarides SE (1981), Contribution to the study of Halloumi cheese. Journal of Agricultural Research, 5, 441-450.

[3] Economides S, Georghiades E, Mavrogenes AP (1987), The effect of different milks on the yeald and chemical composition of Halloumi cheese. Technical bulletin, 90, 2-7.

[4] Shaker RR (1988), Technological aspects of the manufacture of Halloumi cheese. Ph.D. Diss., Massey Univ., Palmerston North, N. Z..

[5] Kakimov A, Kakimova Z, Mirasheva G, Bepeyeva A, Toleubekova S, Jumazhanova M, Zhumadilova G, Yessimbekov Z (2017),.Amino acid composition of sour-milk drink with encapsulated probiotics. Annual Research \& Review in Biology, 18 (1), 1-7.

[6] Getaneh G, Mebrat A, Wubie A, Kendie H (2016) Review on goat milk composition and its nutritive value. Journal of Nutrition and Health Science, 3(4), 401.

[7] Yangilar F (2013), As a potentially functional food: Goats' milk and products. Journal of Food and Nutrition Research, 1(4), 68-81.

[8] Mironenko IM (2016), Feature of the behavior of calcium in the formation of milk clots. Part 1.Functional features of calcium. Cheese and buttermaking Journal, 5, 35-38.

[9] Gorelik OV, Shatskikh EV, Rebezov MB, Kanareikina SG, Kanareikin VI, Likhodeevskaya OE, Andrushechkina N, Harlap S, Temerbayeva M, Dolmatova I, Okuskhanova E (2017), Study of chemical and mineral composition of new sour milk bio-product with sapropel powder. Annual Research \& Review in Biology, 18 (4), 1-5.

[10] Silaeva VM, Sakharov SD (2009), Normalization of milk. Does she always need a cheese maker? // GNU Siberian Research Institute of
Cheese Making. Available from: http://www.dairynews.ru/news/normalizacija_moloka_vsegda_li_o na_nuzhna_syrodela1972.htm Data accessed: 04.08.2009

[11] The optimal fat/protein balance in cheesemaking is your extra profit. Available from: https://soyuzopttorg.com/publikatsii/optimalnyj_balans_zhir_belok _v_syrodelii

[12] Shchetinina EM, Khamagaeva IS (2016), Experimental study of the milk-coagulating activity of enzyme preparations in the milk of agricultural animals. Bulletin of OmGAU, 2(23), 235-241.

[13] Sturova YG, Krieger AV, Bezborodova EO (2013), Effect of temperature and active acidity on milk-coagulating enzyme preparations of animal origin. Polzunov's bulletin, 4(4), 95-99.

[14] Kriger AV, Determination of the ratio between pepsin and chymosin in milk-coagulating enzyme preparations. Available from: http://www.dairynews.ru/news

[15] Tsikunib AD, Goncharova SA (2014), Milk clotting enzymes: a comparative characteristic. Scientific Information Journal of the Institute of Complex Problems of the AGU, 4, 26-31.

[16] Anifantakis EM, Kaminarides SE (1983), Contribution to the study of Halloumi cheese made from sheep's milk. Australian Journal of Dairy Technology, 58, 29-31.

[17] GOST 32260-2013 Semihard cheese. Specification. Moscow, 2014 